\title{
Gambaran Polimorfisme Gen SLC22A1 rs683369 pada Pasien Diabetes Melitus Tipe 2 yang Mendapatkan Terapi Metformin
}

\author{
Rahmatul Firdaushty ${ }^{1}$, Elly Usman ${ }^{2}$ Linosefa $^{3}$
}

\begin{abstract}
Abstrak
Mekanisme kerja metformin dipengaruhi oleh Organic Cation Transporter 1 (OCT1) yang dikode oleh gen SLC22A1. Variasi atau polimorfisme pada gen SLC22A1 mempengaruhi uptake metformin ke hati sehingga berhubungan dengan efek metformin dalam menurunkan glukosa darah. Rs683369 merupakan salah satu polimorfisme dari gen SLC22A1. Tujuan: Melihat gambaran polimorfisme gen SLC22A1 rs683369 pada pasien diabetes melitus tipe 2 yang mendapatkan terapi metfomin. Metode: Penelitian ini merupakan studi deskriptif dengan teknik consequtive sampling. Sampel berasal dari 44 pasien DM tipe 2 yang mendapatkan terapi tunggal metformin yang diambil darahnya melalui pembuluh vena untuk dilakukan pemeriksaan genotip dengan cara isolasi DNA, PCR dan sekuensing. Hasil: Didapatkan pasien DM tipe 2 yang mendapatkan terapi tunggal metformin sebagian besar adalah perempuan 63,6\%, dan rerata umur 55,77 $\pm 7,77$ tahun. Pemerikaan genotip didapatkan hasil wild type (GG) 4,5\%, mutan heterozigot (GC) 22,\%, dan mutan homozigot (CC) 72,7\%. Simpulan: Ditemukan polimorfisme gen SLC22A1 rs683369 pada pasien DM tipe 2 yang mendapatkan terapi metformin. Perlu penelitian lebih lanjut mengenai variasi lain pada gen SLC22A1 dan efeknya terhadap gula darah pasien.
\end{abstract}

Kata kunci: DM Tipe 2, Metformin, OCT1, SLC22A1, Polimorfisme.

\begin{abstract}
The mechanism of metformin action influenced by Organic Cation Transporter 1 (OCT1) that encoded by SLC22A1 gene. The variation or polymorphisms of SLC22A1 affect the uptake of metformin to the liver that associated with the effect of metformin in reducing blood glucose. Rs683369 is one of the polymorphisms of the SLC22A1 gene. Objectives: To evaluated the frequency of SLC22A1 rs683369 in type 2 diabetes mellitus patients with metformin therapy. Methods: This was a descriptive using consequtive sampling. Samples were taken from 44 type 2 diabetes mellitus patients with monotherapy metformin which their blood was taken through veins for genotype test that were DNA isolation, PCR, and sequencing. Results: The most of type 2 diabetes mellitus patients with monotherapy metformin

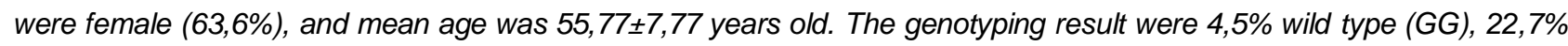
heterozygous variant (GC), and 72,7\% homozygous variant (CC). Conclusion: There is polymorphism of SLC22A1 rs683369 appears in type 2 diabetes mellitus patients with metformin therapy. Further study is needed to evaluate the frequency of other polymorphisms in the SLC22A1 gene and its effect on blood glucose.
\end{abstract}

Keywords: Type 2 DM, Metformin, OCT1, SLC22A1, Polymorphisms.

Affiliasi penulis: 1. Prodi Pendidikan Dokter, Fakultas Kedokteran, Universitas Andalas, Padang, Indonesia. 2. Bagian Farmakologi, Fakultas Kedokteran, Universitas Andalas, Padang, Indonesia. 3. Bagian Mikrobiologi, Fakultas Kedokteran, Universitas Andalas, Padang, Indonesia.

Korespondensi: Elly Usman, Email: ellyusman@med.unand.ac.id Telp: 082169762531

\section{PENDAHULUAN}

Diabetes Melitus (DM) merupakan salah satu masalah kesehatan global darurat terbesar pada abad ke-21 dan menjadi salah satu dari 10 penyebab utama kematian di dunia bersama dengan tiga penyakit mayor Non Communicable Diseases (NCDs) lainnya, yaitu 
penyakit kardiovaskuler, kanker, dan penyakit pernapasan. ${ }^{1}$ Diabetes melitus diklasifikasikan menjadi 4 kelompok yaitu DM tipe 1, DM tipe 2, DM gestasional dan DM tipe lain. DM tipe 2 merupakan kasus terbanyak yaitu 90-95 \%. ${ }^{2}$ Diabetes melitus tipe 2 disebut juga dengan non insulin dependent diabetes mellitus (NIDDM) yang terjadi karena resistensi insulin dan umumnya pasien DM tipe 2 mengalami overweight atau obesitas. ${ }^{3}$

Diabetes melitus tipe 2 merupakan penyakit kronis yang memerlukan terapi seumur hidup. Penatalaksanaan pada pasien DM tipe 2 bertujuan untuk meningkatkan kualitas hidup pasien dengan menghilangkan keluhan terkait DM, mengurangi resiko komplikasi akut, mencegah dan menghambat progresivitas penyulit mikroangiopati dan makroangiopati, dengan tujuan akhir yaitu menurunnya morbiditas dan mortalitas akibat DM dengan cara pengendalian glukosa darah, tekanan darah, berat badan dan profil lipid melalui penatalaksanaan secara komprehensif. Pengendalian glukosa darah pasien DM tipe 2 salah satunya dengan terapi farmakologi. Berdasarkan konsensus PERKENI 2015, metformin menjadi pilihan pertama pada sebagian kasus DM tipe 2. ${ }^{4}$ Metformin merupakan obat antihiperglikemik oral yang meningkatkan aktifitas AMP-dependent protein kinase (AMPK) yang menstimulasi oksidasi asam lemak, uptake glukosa, metabolisme non-oksidatif, serta menurunkan lipogenesis dan glukoneogenesis. Proses tersebut akan mengakibatkan terjadinya peningkatan glikogen, menurunnya produksi gula hepatik, meningkatnya sensitifitas insulin, dan menurunnya kadar gula darah. ${ }^{5}$ Metformin juga mengurangi absorpsi glukosa di usus halus, meningkatkan ambilan glukosa dan pemakaiannya, menurunkan berat badan, menurunkan kadar lipid dalam plasma, dan mencegah komplikasi vaskuler. ${ }^{6}$

Respon metformin pada setiap individu berbedabeda, hal ini disebabkan adanya perbedaan profil genetik dimana terjadi variasi atau polimorfisme pada gen yang berperan dalam sintesis protein yang diperlukan untuk transpor metformin ke dalam sel. ${ }^{7}$ Variasi yang terjadi tidak selalu mengakibatkan perubahan asam amino, namun jika mengakibatkan perubahan pada asam amino maka disebut dengan Nonsynonymous varian. $^{8}$ Hal tersebut akan berpengaruh terhadap kerja transporter obat dimana efek tersebut dapat dilihat pada profil glukosa darah ataupun $\mathrm{HbA} 1 \mathrm{c}$ pasien. Variasi atau polimorfisme pada gen SLC22A1 berhubungan dengan efek metformin dalam menurunkan kadar glukosa darah, seperti pada penelitian yang dilakukan oleh Becker et al pada varian rs622342 ditemukan kurang efektifnya kerja metformin dalam menurunkan glukosa darah dan $\mathrm{HbA1c}$ pada pasien yang membawa alel minor $\mathrm{C}$ dibandingkan wildtype. ${ }^{9}$ Penelitian yang dilakukan Umamaheswaran et al, menemukan adanya hubungan yang signifikan antara rs622342 dengan respon metformin dimana pasien dengan genotip AA 5,6 kali lebih baik responnya terhadap metformin dibandingkan dengan genotip CC. ${ }^{10}$

Efek tersebut disebabkan gen SLC22A1 merupakan gen yang berperan dalam sintesis Organic Cation Transporter 1 (OCT1). OCT1 merupakan protein transporter yang mempengaruhi transpor metformin dari enterosit ke cairan interstitial, uptake metformin ke hepatosit, dan reabsorpsi metformin di tubulus ginjal. ${ }^{6}$ Polimorfisme gen SLC22A1 pada manusia sangat tinggi. Penelitian Kerb et al adalah yang pertama kali menjelaskan bahwa terdapat 25 variasi polimorfisme pada ras kaukasia pada gen SLC22A1 dan sampai sekarang telah ditemukan lebih dari 1000 polimorfisme OCT1 pada manusia. ${ }^{11}$ Beberapa variasi tersebut diantaranya rs34447885, rs35888596, rs12208357, rs55918055, rs200684404, rs683369, rs34104736, rs36103319, rs4646277, rs2282143, rs34205214, rs34130495, rs628031, rs202220802, rs34305973, rs35191146, rs35167514, rs72552763, rs35956182, rs34295611, rs34059508, rs35270274, rs78899680, dan rs622342. Pada rs683369 ditemukan pada hampir semua etnik dengan ras Kaukasia, Afrika, Asia dan Amerika memiliki frekuensi alel lebih dari $1 \%{ }^{12}$

Berdasarkan uraian diatas, ditemukannya polimorfisme gen SLC22A1 rs683369 di Asia dan belum adanya data mengenai gambaran polimorfisme gen SLC22A1 rs683369 pada pasien diabetes melitus tipe 2 yang mendapatkan terapi metformin di Kota Padang, maka peneliti tertarik untuk melakukan penelitian tentang gambaran polimorfisme gen SLC22A1 rs683369 pada pasien diabetes melitus tipe 2 yang mendapatkan terapi metformin. 


\section{METODE}

Jenis penelitian ini adalah studi deskriptif dengan rancangan cross sectional. Penelitian dilakukan di Puskesmas Kota Padang dan Laboratorium Biomedik Fakultas Kedokteran Universitas Andalas pada periode Oktober 2018-Juli 2019.

Populasi pada penelitian ini adalah semua pasien yang didiagnosis DM Tipe 2 oleh dokter di Puskesmas Kota Padang. Sampel yang dipilih pada penelitian ini adalah bagian dari populasi yang memenuhi kriteria inklusi dan tidak memiliki kriteria eksklusi.

Kriteria Inklusi:

1. Pasien yang didiagnosis DM tipe 2 oleh dokter di Puskesmas Kota Padang.

2. Pasien DM tipe 2 usia 20-65 tahun.

3. Pasien DM tipe 2 yang mendapatkan monoterapi metformin.

Kriteria Eksklusi:

1. Pasien DM tipe 2 dengan gangguan hati

2. Pasien DM tipe 2 dengan gangguan ginjal

3. Pasien DM tipe 2 dengan penyakit keganasan seperti keganasan pada hati dan ginjal.

4. Pasien DM tipe 2 yang hamil dan menyusui.

Sampel berasal dari 44 pasien DM tipe 2 yang mendapatkan terapi tunggal metformin yang diambil darahnya melalui pembuluh vena untuk dilakukan pemeriksaan genotip dengan cara isolasi DNA, PCR dan sekuensing. Pengolahan dan analisis data dilakukan dengan menggunakan program komputer. Analisis univariat dilakukan untuk mengetahui gambaran masing-masing variabel yang diteliti. Hasilnya berupa frekuensi dan persentase dari variabel yang diteliti.

\section{HASIL}

Data karakteristik diambil dari kunjungan pasien DM tipe 2 di beberapa puskesmas di Kota Padang dengan hasil pada Tabel 1.
Tabel 1 Karakteristik penderita diabetes melitus tipe 2 yang berobat di puskesmas Kota Padang yang mendapatkan monoterapi metformin

\begin{tabular}{lrrrrrr}
\hline \multirow{2}{*}{ Puskesmas } & \multicolumn{4}{c}{ Jenis Kelamin } & \multicolumn{2}{c}{ Total } \\
\cline { 2 - 6 } & \multicolumn{2}{c}{$\mathbf{L}$} & \multicolumn{3}{c}{$\mathbf{P}$} & \multicolumn{2}{c}{} \\
\cline { 2 - 6 } & $\mathbf{f}$ & $\%$ & $\mathbf{f}$ & $\%$ & $\mathbf{f}$ & $\%$ \\
\hline Seberang & 1 & 100 & 0 & 0 & 1 & 2,3 \\
Padang & & & & & & \\
Lubuk Buaya & 13 & 36,1 & 23 & 63,9 & 36 & 81,8 \\
Andalas & 1 & 20 & 4 & 80 & 5 & 11,4 \\
Ulak Karang & 1 & 50 & 1 & 50 & 2 & 4,5 \\
\hline Total & 16 & 36,4 & 28 & 63,6 & 44 & 100
\end{tabular}

L: Iaki-laki, P: Perempuan, f:Frekuensi

Data yang didapatkan menunjukkan pasien DM tipe 2 yang mendapatkan terapi tunggal metformin sebanyak 44 pasien. Jumlah pasien DM tipe 2 yang mendapatkan terapi metformin lebih banyak ditemukan di Puskesmas Lubuk Buaya. Berdasarkan jenis kelamin, pasien perempuan DM tipe 2 yang mendapatkan terapi tunggal metformin (63,6 \%) lebih banyak daripada pasien laki-laki (36,4\%). Berdasarkan umur, rerata umur pasien yang menjadi subjek penelitian adalah $55,77 \pm 7,77$ tahun dengan rentang umur 26-65 tahun. Kategori umur 56-65 tahun memiliki persentase tertinggi (56,8\%). Data karakteristik umur pasien dapat dilihat pada tabel 2 berikut.

Tabel 2. Karakteristik umur penderita diabetes melitus tipe 2 yang berobat di Puskesmas Kota Padang yang mendapatkan monoterapi metformin

\begin{tabular}{ccccccc}
\hline $\begin{array}{c}\text { Umur } \\
\text { (tahun) }\end{array}$ & $\mathbf{f}$ & $\%$ & Rerata & SD & Min & Maks \\
\cline { 1 - 3 } $26-35$ & 2 & 4,5 & & & & \\
$36-45$ & 1 & 2,3 & & & & \\
$46-55$ & 16 & 36,4 & 55,77 & 7,77 & 26 & 65 \\
$56-65$ & 25 & 56,8 & & & & \\
\hline Total & 44 & 100 & & & & \\
\hline
\end{tabular}

Hasil analisis polimorfisme gen SLC22A1 rs683369 pada pasien diabetes melitus tipe 2 yang mendapatkan terapi metformin dapat dilihat di Tabel 3. 
Tabel 3. Analisis hasil sekuensing gen SLC22A1 rs683369

\begin{tabular}{lccc}
\hline \multicolumn{1}{c}{ Hasil Sekuensing } & $\mathbf{f}$ & $\%$ & $\begin{array}{c}\text { Minor Alel } \\
\text { Frekuensi }\end{array}$ \\
\hline GG (wild type) & 2 & 4,5 & \\
GC (mutan heterozigot) & 10 & 22,7 & G $=0,16$ \\
CC (mutan homozigot) & 32 & 72,7 & \\
\hline \multicolumn{1}{c}{ Total } & 44 & 100 & \\
\hline
\end{tabular}

Berdasarkan tabel diatas diketahui bahwa dari 44 sampel, genotip GG (wild type) memiliki persentase terendah yaitu $4,5 \%$ sedangkan genotip CC (mutan homozigot) memiliki persentase tertinggi yaitu $72,7 \%$, dan minor alel frekuensi 0,16.

\section{PEMBAHASAN}

Karakteristik Penderita Diabetes Melitus Tipe 2 yang Berobat di Puskesmas Kota Padang yang Mendapatkan Terapi Metformin

Penelitian ini melibatkan 44 pasien yang didiagnosis diabetes melitus tipe 2 oleh dokter dan mendapatkan monoterapi metformin di beberapa Puskesmas di Kota Padang dengan pasien perempuan $(63,6 \%)$ lebih banyak dibandingkan laki-laki (36,4\%). Penelitian lain yang dilakukan oleh Umamaheswaran et al, pada pasien DM tipe 2 yang mendapatkan monoterapi metformin pada Oktober 2007-Juli 2009 di India juga ditemukan pasien perempuan (61\%) lebih banyak daripada laki-laki (39\%). ${ }^{10}$ Penelitian yang dilakukan oleh Shikata et al, juga didapatkan pasien perempuan (72,7\%) lebih banyak dari laki-laki $(27,3 \%) .{ }^{13}$ Sur Dipanshu dalam penelitiannya terhadap pasien DM tipe 2 yang menggunakan obat metformin di India juga ditemukan pasien perempuan lebih banyak dibandingkan laki-laki. ${ }^{14}$ Penelitian Al-Eitan et al, di Klinik Diabetes Universitas King Abdullah tahun 20142015 dari 212 pasien inklusi, 61,3\% pasien adalah perempuan. ${ }^{15} \mathrm{Hal}$ ini dimungkinkan karena perempuan lebih beresiko mengalami diabetes melitus karena pada perempuan tingkat depresi 2 kali lebih sering daripada laki-laki, riwayat diabetes melitus selama kehamilan dan melahirkan bayi dengan berat badan $>4 \mathrm{~kg}$, perempuan dengan polycistic ovarian syndrom, aktifitas fisik yang kurang, dan obesitas. ${ }^{16,17}$

Berdasarkan umur, rerata usia pasien yang menjadi subjek penelitian adalah $55,77 \pm 7,77$ tahun dengan rentang umur 26-65 tahun, serta kategori umur
56-65 tahun memiliki persentase tertinggi. Penelitian Shikata et al, didapatkan rata-rata umur pasien adalah 62 tahun dengan rentang 29-73 tahun. ${ }^{13}$ Penelitian Umamaheswaran et al, ditemukan rerata umur pasien $49,57 \pm 9,88$ tahun dengan rentang umur 30-76 tahun. ${ }^{10}$ Sur Dipanshu dalam penelitiannya didapatkan rerata umur pasien adalah $46 \pm 12,72$ tahun. ${ }^{14}$ Dari penelitian diatas dapat disimpulkan bahwa terdapat variasi rerata dari segi umur. Berdasarkan ADA 2017, diabetes melitus tipe 2 meningkat seiring bertambahnya usia, dimana usia 45 tahun keatas lebih beresiko tinggi menderita DM tipe $2 .^{3}$

\section{Polimorfisme Gen SLC22A1 rs683369 pada Pasien Diabetes Melitus Tipe 2 yang Mendapatkan Terapi Metformin.}

Hasil sequencing pada penelitian ini didapatkan bahwa dari 44 pasien DM tipe 2 yang mendapatkan monoterapi metformin, 4,5\% diantaranya memiliki genotip GG, 22,7\% genotip GC\%, dan 72,7\% genotip CC dengan frekuensi alel minor 0,16. Penelitian yang dilakukan oleh Shikata et al, pada pasien yang mengonsumsi metformin mendapatkan frekuensi alel G dan alel $\mathrm{C}$ tidak jauh berbeda pada pasien yang mengonsumsi metformin dengan pasien yang tidak mengonsumsi metformin ( 0,13 vs 0,17 dan 0,88 vs $0,87) .{ }^{13}$ Penelitian lain yang dilakukan oleh Al-Eitan et al, di Jordan dari 212 pasien DM tipe 2 yang medapatkan metformin, 160 responden ditemukan genotip CC, 50 responden genotip GC, dan 2 responden genotip GG dengan frekuensi alel minor ( alel G ) 0,13 . Pada penelitian ini didapatkan tidak adanya efek signifikan antara rs683369 dengan kadar HbA1c pasien $(p>0,05) .{ }^{15}$

Penelitian lain pada pasien polycistic ovarium sindrom (PCOS) yang mengonsumsi metformin oleh Chang et al, di Taiwan mendapatkan genotip CC 73,6\%, genotip GC 25,3\%, dan genotip GG 1,1 \% dengan frekuensi alel minor 0,138. Chang et al, juga meneliti rs683369 pada subjek sehat sebagai kontrol dengan hasil genotip CC 71,7 \%, genotip GC 28,3\%, dan genotip GG 0\% dengan frekuensi alel 0,142. Pada penelitian tersebut dapat disimpulkan genotip CC memiliki persentase paling tinggi dan genotip GG paling rendah, baik pada pasien PCOS maupun subjek sehat, serta distribusi frekuensi yang tidak berbeda secara 
signifikan diantara keduanya. Pasien dengan polimorfisme pada OCT1 ditemukan adanya perbedaan yang signifikan antara sensitifitas insulin setelah terapi metformin dan adanya interaksi yang signifikan antara metformin dengan OCT1 dimana pada penelitian ini ditemukan pasien dengan alel $G$ pada rs683369 dan/atau alel A pada rs628031 terjadi peningkatan sensitifitas insulin setelah diberikan terapi metformin. ${ }^{18}$

Penelitian lain mengenai rs683369 pada pasien leukemia mieloid kronik dengan terapi nilotinib di Italia oleh Galimberti et al, juga menemukan persentase genotip CC paling tinggi dan genotip GG paling rendah dengan rincian hasil genotip CC 64\%, GC 30,7\%, dan GG 5,3\%, frekuensi alel C 79,3\% dan alel G 20,7\%. Pada penelitian tersebut pasien dengan polimorfisme OCT1 tidak berdampak pada efikasi ataupun toksisitas nilotinib pada terapi leukemia mieloid kronik. ${ }^{19}$ Berdasarkan data 1000 genomes project phase 3, di populasi Asia Timur didapatkan genotip CC 74,2\%, GC 22,4\%, dan GG 3,4\% dengan frekuensi alel G 0,146 dan alel C 0,854. Pada populasi Asia Selatan genotip CC 70,1\%, GC 25,4\%, GG 4,5\% dengan frekuensi alel G 0,172, dan alel C 0,828. Populasi Afrika ditemukan genotip CC 97,9\%, GC 2,1\% dengan frekuensi alel G 0,011 dan alel G 0,989. Pada populasi Eropa genotip CC memiliki frekuensi $62,2 \%$, GC 32,6\%, dan GG 5,2 $\%$ dengan frekuensi alel G 0,215 dan alel C 0,785. ${ }^{20}$ Heterogennya gen SLC22A1 bersifat ethnic specific. Populasi Kaukasia, Afrika, dan Amerika memiliki variasi yang lebih tinggi dari Asia dan Pasifik. Pada studi polimorfisme, hanya varian M408V yang ditemukan pada semua etnik dan merupakan satu-satunya varian yang teridentifikasi di Pulau Pasifik. ${ }^{12}$

\section{SIMPULAN}

Ditemukan adanya polimorfisme gen SLC22A1 rs683369 dengan genotip wild type, varian homozigot, dan varian heterozigot pada penderita diabetes melitus tipe 2 yang mengonsumsi metformin.

\section{SARAN}

Perlu dilakukan pemeriksaan SNP gen SLC22A1 lainnya, serta dapat dilakukan pemeriksaan gula darah atau $\mathrm{HbA} 1 \mathrm{c}$ pasien untuk melihat hubungan polimorfisme dengan kontrol glikemik pasien.

\section{UCAPAN TERIMA KASIH}

Terima kasih kepada semua pihak yang telah berpartisipasi dalam penelitian ini. Kepada Kepala Dinas Kesehatan Kota Padang, Puskesmas Kota Padang, dan Laboratorium Biomedik Fakultas Kedokteran Universitas Andalas yang telah membantu penulis dalam menyelesaikan penelitian ini.

\section{DAFTAR PUSTAKA}

1. International Diabetes Federation (IDF). Diabetes atlas $8^{\text {th }}$ edition (diakses Mei 2018). Tersedia dari: http://www.diabetesatlas.org

2. American Diabetes Association (ADA). Diagnosis and classification of diabetes mellitus. Diabetes Care. 2010; 33(suppl.1): S63-5.

3. American Diabetes Association (ADA). Standards of medical care in diabetes. Diabetes Care. 2017; 40 (Suppl. 1): S16.

4. Perkumpulan Endokrinologi Indonesia (PERKENI). Konsensus pengelolaan dan pencegahan diabetes melitus tipe 2 di Indonesia 2015. Jakarta: PB PERKENI; 2015.

5. Brunton L, Chabner B, Knollman B. Goodman\&gillman's: The pharmacological basis of therapeutics. Dalam: Powers AC, D'Alessio D, editor (penyunting). Endocrine pancreas and pharmacotherapy of diabetes mellitus and hypoglycemia. Edisi ke-12. New York: McGraw Hill Education; 2011.hlm.1258.

6. Gong L, Goswami S, Giacomini KM, Altman RB, Klein TE. Metformin pathways: Pharmacokinetics and pharmacodinamics. Pharmacogenet Genomics. 2012; 22(11): 820-7.

7. Todd JN, Florez JC. An update on the pharmacogenomics of metformin: Progress, problems and potential. Pharmacogenomics. 2014; 15(4): 529-39.

8. Ismail S, Essawi M. Genetic polymorphism studies in human. Middle East J Med Genet. 2012; 1(2): 57-63.

9. Becker ML, Visser LE, Schaik RHNV, Hofman A, Uitterlinden AG, Stricker BHC. Genetic variation in the organic cation transporter 1 is associated with metformin response in patients with diabetes mellitus. Pharmacogenomics J. 2009; 9: 242-7. 
10. Umamaheswaran G, Praveen RG, Damodaran SE, Das AK, Adithan C. Influence of SLC22A1 rs622342 genetic polymorphism on metformin response in South Indian type 2 diabetes mellitus patients. Clin Exp Med. 2015; 15(4): 511-7.

11. Kerb R, Brinkmann U, Chatskaia N, Gorbunov D, Gorboulev V, Mornhinweg E, et al. Identification of genetic variations of the human organic cation transporter hOCT1 and their functional consequences. Pharmacogenetics. 2002;12:591-5.

12. Arimany-Nardi C, Koepsell $H$, Pastor-Anglada $M$. Role of SLC22A1 polymorphic variants in drug disposition, therapeutics response, and drug-drug interactions. Pharmacogenomics J. 2015: 1-15.

13. Shikata E, Yamamoto $R$, Takane $H$, Shigemasa $C$, Ikeda $\mathrm{T}$, Otsubo $\mathrm{K}$, et al. Human organic cation transporter (OCT1 and OCT2) gene polymorphisms and therapeutic effects of metformin. J Hum Genet. 2007;52:117-22.

14. Sur D. A tale of genetic variation in the human SLC22A1 gene encoding OCT1 among type 2 diabetes mellitus population groups of west bengal, india. Impact Journals. 2014; 2(5):97-106.

15. Al-Eitan LN, Almomani BA, Nassar AM, Elsaqa BZ, Saadeh NA. Metformin pharmacogenetics: Effects of SLC22A1, SLC22A2, SLC22A3 polymorphisms on glycemic control and $\mathrm{HbA} 1 \mathrm{c}$ levels. J.Pers.Med. 2019; 9(17):1-11.

16. Kasper, Fauci, Hauser, Longo, Jameson, Loscalzo. Harrison's principle of internal medicine. Dalam: Powers AC, editor (penyunting). Diabetes mellitus: Diagnosis, classification, and patophysiology. Edisi ke-19. New York: McGraw Hill Education; 2015. hlm.2401.

17. American Diabetes Association (ADA). Woman and Diabetes (diakses April 2019). Tersedia dari: http://www.diabetes.org.

18. Chang HH, Hsueh YS, Cheng YW, Ou HT, Wu MH. Association between polymorphism of OCT1 and metabolic response to metformin in woman with polycistic ovarian sindrom. Int.J.Mol.Sci. 2019; 20 (7):1720.

19. Galimberti S, Bucelli C, Arrigoni E, Barate C, Grassi S, Ricci F. The hOCT1 and ABCB1 polymorphism do not influence the pharmacodynamics of nilotinib in chronic myeloid leukemia. Oncotarget. 2017; 8(50): 88021-88033.

20.1000 Genomes Project. Rs683369 populations genetic 1000 genomes project phase 3. (diakses Juli 2019). Tersedia dari: http://www.ensembl.org. 